\title{
Spatio-temporal attributes of water temperature and macroinvertebrate assemblages in the headwaters of the Bushmans River, southern Drakensberg
}

\author{
Stefan Grab* \\ School of Geography, Archaeology and Environmental Studies, University of the Witwatersrand, P/Bag 3, WITS 2050, South Africa
}

\section{ABSTRACT}

Currently, there is little understanding of the controls that instream thermal limits and hydraulic biotype diversity have on macroinvertebrate assemblages, particularly in association with changing altitude within given southern African mountain drainage systems. Thus, the aim of this research was to examine aquatic macroinvertebrate assemblage changes in response to spatial and temporal geo-hydrological contexts (temperature and hydraulic biotype) along the upper Bushmans River, southern Drakensberg. Instream temperature was continuously logged at 3 altitudes (1 760, 2 030, 2280 $\mathrm{m}$ amsl) along the Bushmans River to the east of the Great Escarpment, and in the headwaters of the Sani River (2 $860 \mathrm{~m}$ amsl) to the west of the escarpment, for the period January-May 2007. Aquatic macroinvertebrates were sampled during early December 2006, late March 2007, and late May 2007. The study demonstrates that decreasing water temperatures, both spatially (with increasing altitude) and seasonally (from summer to winter), and/or decreasing diversity of hydraulic biotypes associated with stream-channel narrowing in Drakensberg rivers/streams, are associated with a general decrease in the absolute number of macroinvertebrate families, a lower dissimilarity coefficient along the Bushmans River altitudinal transect, and a decreasing variance in the numbers of macroinvertebrate families across various hydraulic biotypes.

Keywords: Aquatic macroinvertebrates, water temperature, hydraulic biotypes, Drakensberg

\section{INTRODUCTION}

Considerable international work has focused on macroinvertebrate assemblages in a variety of fluvial settings (e.g. Power et al., 1995; Céréghino et al., 2001; Wong et al., 2004; Compin and Céréghino, 2007). Apart from the focus on understanding instream macroinvertebrate biology (e.g. Céréghino et al., 2001; Moor and Palmer, 2005), a primary research thrust has been on developing theories and models on the abiotic controls of in-stream macroinvertebrate species composition, community structures, fine-scale spatial distributions, and associated ecosystem functioning. Emphasis has been on how channel geomorphology (e.g. Huryn and Wallace, 1987; Lamberti et al., 1989; Brown and Brussock, 1991; Wang et al. 2009), channel substratum and sediment delivery, entrainment and deposition (e.g. Beisel et al., 1998; Larsen and Ormerod, 2010), and channel flow regimes including water velocity and depth (e.g. Jowett and Richardson, 1990; Dewson et al., 2007), may influence macroinvertebrate assemblages. Important controls influencing the spatial variability of macroinvertebrate species richness and abundance in mountain catchments include hydraulic biotypes (e.g. Bonada et al., 2006; Davy-Bowker et al., 2006; Curry et al., 2012) and fluvialenvironmental changes associated with altitudinal gradients (e.g. Andrew et al., 2003; Jacobsen, 2004). In addition, there has been growing concern and emphasis on establishing climate change impacts on mountain stream temperatures and

To whom all correspondence should be addressed

Iil +27 11717 6512; fax: +27 11717 6529;

e-mail: Stefan.grab@wits.ac.za

Received 20 January 2013; accepted in revised form 10 December 2013. consequent implications for aquatic biosystems (including aquatic macroinvertebrates) (e.g. Hari et al., 2006; Durance and Ormerod, 2007; Chessman, 2009; Lawrence et al., 2010).

Hydrobiological studies have a relatively long and well established history in South Africa, having emerged from the early descriptive approaches by the likes of Barnard (1927) and Hutchinson (1929) but then gradually becoming more applied towards bioassessments for river ecosystem and health functions (e.g. Chutter, 1972, King and Louw, 1998; Roux et al., 1999; Dickens and Graham, 2002; Bate et al., 2004; Dallas, 2004, 2007; Ollis et al., 2006; Malherbe et al., 2010). Although it is internationally well recognised that altitudinal gradients and associated water temperatures impact macroinvertebrate diversity, community structure and survival (e.g. Jacobsen et al., 1997; Cox and Rutherford, 2000; Smith et al., 2003; Finn and Poff, 2005), there has been little, if any, work in southern Africa investigating altitudinal trends in mountain water temperatures and the associated aquatic macroinvertebrate population biology. To this end, the aim of this study was to provide a preliminary investigation into aquatic macroinvertebrate assemblage changes in response to spatial geo-hydrological and temporal contexts along the upper Bushmans River, southern Drakensberg. In so doing, hydrological (or hydro-geomorphological) biotypes (Rowntree and Wadeson, 1999) and their linkages to sediment supply and habitat heterogeneity were recognised and considered (Yarnell et al., 2006), which consequently define the riverine microhabitats and macroinvertebrate structures.

\section{STUDY SITE AND METHODS}

The upper Sani and Bushmans Rivers are located in the Ukhahlamba Drakensberg Park and should represent 'pristine' stream settings with limited anthropogenic impacts 


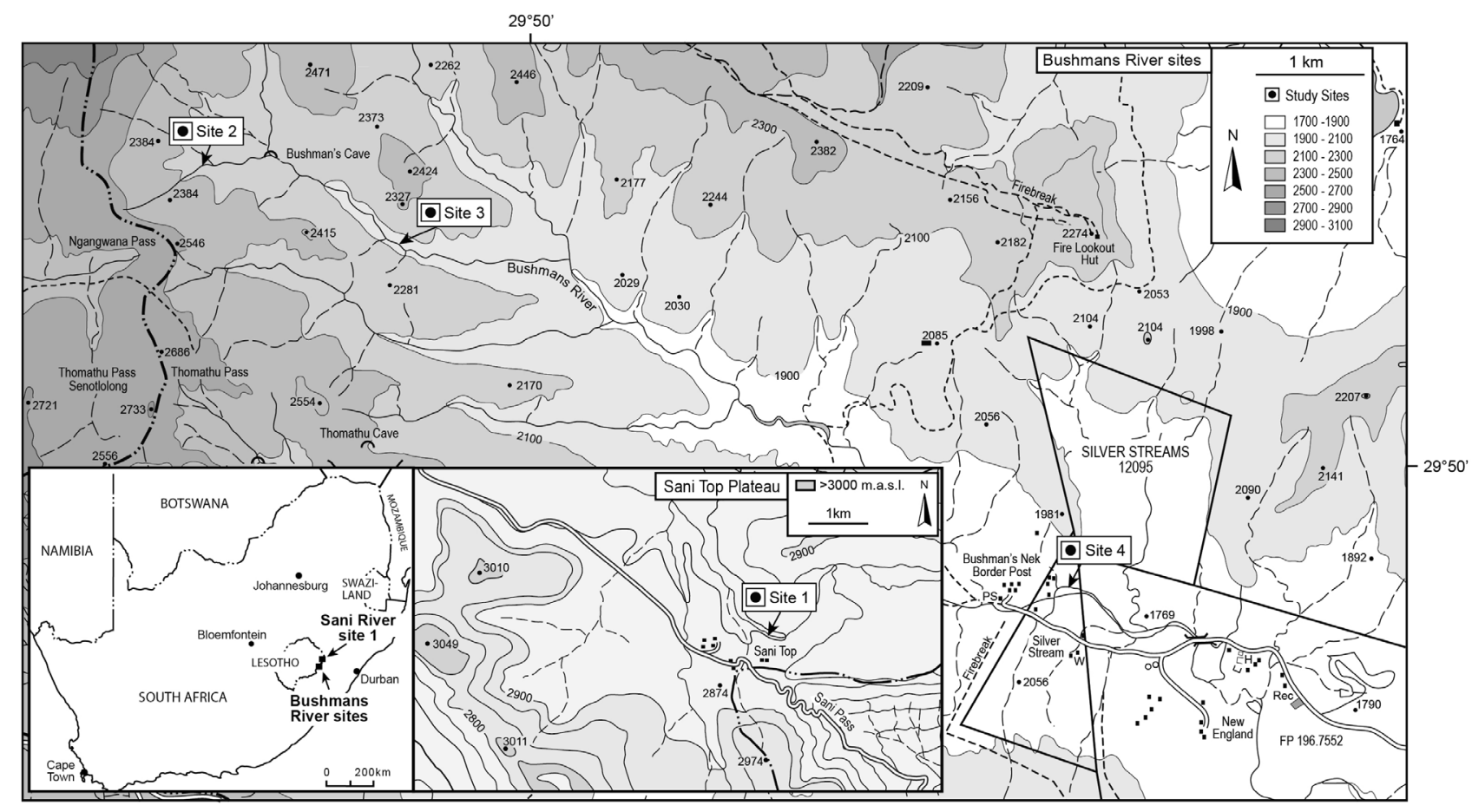

Figure 1

Location of the Sani and Bushmans River study regions and specific sampling sites along the Bushmans and Sani Rivers

on water quality. Site selection (see Fig. 1) was based on the stream zonation classifications described by Rowntree and Wadeson (1999):

- Site 1 is the upper Sani River $\left(2860 \mathrm{~m}\right.$ amsl.; $29^{\circ} 24.783 \mathrm{~S}$, $\left.29^{\circ} 17.366 \mathrm{E}\right)$ on the Lesotho plateau and is included primarily for assessing altitudinal changes in water temperature to the Drakensberg summit or alpine zone (hereafter referred to as 'Sani site'). Domestic livestock grazing occurs in this catchment.

- Site 2: Upper mountain stream, Bushmans River - bedrock dominated and a narrow flow channel. The site is located at $2280 \mathrm{~m}$ amsl; $29^{\circ} 48.462 \mathrm{~S}, 29^{\circ} 08.000 \mathrm{E}$ (hereafter referred to as 'upper site').

- Site 3: Mountain stream, Bushmans River - a steep fluvial gradient (0.01-0.07) dominated by bedrock and boulders with pool morphology, waterfalls and rapids. Locally, cobble and course gravels form plane beds. A floodplain is generally absent but lateral depositional bench type features occur. The site is located at $2030 \mathrm{~m}$ amsl; $29^{\circ} 48.819$ $\mathrm{S}, 29^{\circ} 09.147 \mathrm{E}$ (hereafter referred to as 'mid site').

- Site 4: Foothills, Bushmans River - moderately steep channel (gradient 0.002-0.008), gravel/cobble bed commonly with pool-riffle or pool-rapid morphology, locally bedrock controlled. Narrow floodplain of sand and/or gravel, and the channel pattern is meandering or braided. The site is located at $1760 \mathrm{~m}$ amsl; $29^{\circ} 50.575 \mathrm{~S}, 29^{\circ} 12.979$ E (hereafter referred to as 'lower site').

All sites comprised similar stream flow types (i.e. pools, riffles, backwaters). In 'backwater' regions, flow is classified according to Rowntree and Wadeson (1999) as barely perceptible (i.e. smooth surface, flow only perceptible through the movement of suspended matter). Regions of 'slack water' had no flow but sites were mainly characterised by 'chaotic flow' (complex mixture of continuously varying flow types (Rowntree and Wadeson, 1999)), which become gradually smoother downstream towards Site 3 .

It was ensured that selected sampling sites had varied micro-geomorphological habitats to permit comparative analyses. Calibrated Hobo TidbiT v2 water temperature loggers were installed and anchored to the stream bed (within the primary flow channel) at each site in December 2006. The Hobo loggers have an accuracy of $0.2^{\circ} \mathrm{C}$ and recorded water temperatures at an hourly logging interval between 7 December 2006 and 24 May 2007.

Macroinvertebrates were sampled during early December 2006 (summer), late March 2007 (autumn), and late May 2007 (early winter). Sampling techniques should suit the hydrological biotype, thus both kick-sampling and hand-sampling were used. Although 7 hydrological biotypes were selected per research site, where one or more biotypes were absent, additional sampling was undertaken for those biotypes represented. The hydrological biotypes in this study, as classified and defined by Rowntree and Wadeson (1999), included back waters and slack waters connected to the river, chutes, riffles and glides. Quantitative macroinvertebrate abundance could not be determined given the complexity of hydrologic biotypes which jeopardises the accuracy of counts. Thus, the relative abundance was determined using a rating score as follows: $1=1$ individual; $5=2-5$ individuals; $10=6-10$ individuals; $50=11-50$ individuals; $100=\geq 51$ individuals. Total scores were obtained for each hydrologic biotype and a 'maximum abundance' score determined for each family across the 7 biotypes sampled per site. Water temperature and $\mathrm{pH}$ readings were taken at the deepest position at sampling sites during field visits.

A zero-adjusted Bray-Curtis coefficient, following Clarke et al. (2006), was used to establish the extent of macroinvertebrate family resemblance (i.e. similarity or dissimilarity) measured at the upper-, mid- and lower-Bushmans River sites during various seasons (summer, autumn, winter) in 


\section{TABLE 1}

Water $\mathrm{pH}$ and conductivity values at the Sani and Bushmans River sites during summer, autumn and winter of 2006/07

\begin{tabular}{|l|c|c|c|}
\hline \multirow{2}{*}{ Site } & \multicolumn{3}{|c|}{$\mathrm{pH}$} \\
\cline { 2 - 4 } & Summer & Autumn & Winter \\
\hline Sani River & 7.01 & 7.05 & 6.92 \\
\hline Bushmans River, Site 1 & 7.02 & 7.24 & 7.10 \\
\hline Bushmans River, Site 2 & 7.02 & 6.15 & 6.95 \\
\hline Bushmans River, Site 3 & 7.02 & 6.96 & 7.02 \\
\hline Conductivity (mS/m) & & & \\
\hline Sani River & 0.3 & 0.08 & 0.15 \\
\hline Bushmans River, Site 1 & 0.08 & 0.11 & 0.10 \\
\hline Bushmans River, Site 2 & 0.1 & 0.05 & 0.1 \\
\hline Bushmans River, Site 3 & 0.08 & 0.06 & 0.12 \\
\hline \multirow{2}{*}{$\begin{array}{l}\text { Tolerance levels after Dallas } \\
\text { et al. (1999): }\end{array}$} & \multicolumn{3}{|c|}{ pH } \\
\cline { 2 - 4 } Heptageniidae & Ave. & Min. & Max. \\
\cline { 2 - 4 } & 7.19 & 5.3 & 8.58 \\
\cline { 2 - 4 } & \multicolumn{3}{|c|}{ Conductivity (mS/m) } \\
\cline { 2 - 4 } & Ave. & Min. & Max. \\
\cline { 2 - 4 } & 14.9 & 1.7 & 54.1 \\
\hline
\end{tabular}

2006/2007. The modified Bray-Curtis coefficient is designed to cater for denuded samples, and is apparently 'more interpretable and statistically significant' than most other alternatives (Clarke et al., 2006, p. 78).

\section{RESULTS AND DISCUSSION}

\section{Water quality}

Water $\mathrm{pH}$ levels remained close to neutral at all sites from mid-summer through to early winter and averaged 6.96 across all sites and seasons, apart for the mid site which recorded a slight increase in acidity ( $\mathrm{pH}$ 6.15) during autumn (Table 1). In addition, water conductivity levels remained low at all sites and during all seasons (mean $=0.09 \mathrm{mS} / \mathrm{m}$ ). Water conductivity, in particular, influences macroinvertebrate richness and diversity (Miserendino, 2001; Azrina et al., 2006; Stenert et al., 2008). In South Africa, Dallas et al. (1999) have established $\mathrm{pH}$ and conductivity tolerance levels for macroinvertebrate families, including Heptageniidae (Table 1), which was present in the Bushmans River. While pH levels in the Bushmans River were positioned within suitable tolerance levels, conductivity levels were lower than the minimum threshold levels identified by Dallas et al. (1999). Given the low spatial and temporal variance in $\mathrm{pH}$ and conductivity levels along the upper Bushmans River, these are unlikely abiotic controls on the spatial and temporal macroinvertebrate population dynamics.

\section{Water temperatures and lapse rates}

Water temperature is considered one of the most important parameters influencing river health and freshwater ecology (Webb et al., 2008). Although there has been considerable interest in water temperature effects on riverine ecosystems in southern Africa (see Dallas, 2007, 2008 for a review), there is a notable absence of such data from the high altitude Lesotho and other southern African mountains such as the Drakensberg. There is an additional regional gap of knowledge on how such mountain stream water temperatures vary altitudinally. The current paper thus provides some preliminary data in this regard. River/stream water temperatures are influenced by a host of multi-scale (regional to micro-level) factors which may be grouped into hydrological, climatic and structural controls (Dallas, 2008). However, given that these multiple factors have influences and magnitudes which are difficult to ascertain independently, and in addition operate synergistically, it is exceptionally difficult to accurately quantify the extent to which factors contribute towards fine-scale water temperature variability (Clark et al., 1999; Johnson, 2004).

Water temperatures in the upper reaches of the Sani and Bushmans Rivers were spatially and temporally highly variable. Mean monthly summer temperatures (Jan/Feb) varied from $18.5^{\circ} \mathrm{C}$ (lower site at $1760 \mathrm{~m}$ amsl) to $14.6^{\circ} \mathrm{C}$ (upper site at $2280 \mathrm{~m}$ amsl) and reached a maximum of $26.9^{\circ} \mathrm{C}$ at Site 1 (Table 2). Notably, mean summer water temperatures in the upper Sani River (approx. $15.4^{\circ} \mathrm{C}$ at $2860 \mathrm{~m}$ amsl) were higher than those in the upper Bushman's River at $2280 \mathrm{~m}$ amsl (approx. $14.7^{\circ} \mathrm{C}$ ), but similar to those at $2080 \mathrm{~m}$ amsl (approx. $15.6^{\circ} \mathrm{C}$ ). The altitudinal water cooling associated with free air cooling was likely complicated by the rate of altitudinal change in association with stream distance and site-specific stream flow dynamics (depth-width ratios, heating effects of instream substrates). Thus, the relatively short distance (approx. $2 \mathrm{~km}$ ), combined with a steep mean flow gradient $(0.1 \mathrm{~m} / \mathrm{m})$ between the upper and mid sites, accounted for relatively low water temperature lapse rates during summer $\left(\right.$ mean $=-0.45^{\circ} \mathrm{C} / 100$ $\mathrm{m}$ ). In contrast, the longer distance (approx. $7.2 \mathrm{~km}$ ) and considerably shallower flow gradient $(0.04 \mathrm{~m} / \mathrm{m})$ between the mid and lower sites, accounted for a doubling of water lapse rates (approx. $0.90^{\circ} \mathrm{C} / 100 \mathrm{~m}$ ). The resulting slower velocity of flow, greater unit water contact with rock/boulder surfaces and associated greater solar heating of bedrock and boulders as the valley widens downstream, are likely factors contributing to rapid stream temperature increases through the foothill zone. Similar inferences have been made by others suggesting that streams flowing over rock-dominated reaches may be more temperature responsive to slight changes in incoming solar radiation than those flowing over other substrates (Brown, 1969; Moore et al., 2005; Webb et al., 2008). Such factors may also account for the unexpectedly high mean summer temperatures of the Sani River, which is a relatively wide, boulder-dominated channel exposed to substantial incoming solar radiation, especially given the wide and open topographic setting. In addition, these stream sections had a high mean diurnal range of summer water temperatures, averaging $11.2^{\circ} \mathrm{C}(\mathrm{Feb})$ and $6.8^{\circ} \mathrm{C}$ (Jan) for the Sani and lower Bushmans River sites, respectively, whilst extreme diurnal ranges in water temperature were as high as $16.8^{\circ} \mathrm{C}$ and $10.9^{\circ} \mathrm{C}$, respectively. An understanding of such water temperature dynamics may be important when projecting likely future water temperatures for mountain streams (and associated impacts on biota) under global change scenarios. For instance, greater extremes in air temperature are likely to further enhance the diurnal range of water temperatures and may ultimately exceed tolerance threshold values for some biota within hydrologic biotypes along particular altitude-specific zones. To this end, identifying channel sections in which contemporary water temperatures have a high diurnal range may be an important task in the context of establishing which channel sections are likely to be subject to the most extreme future temperature changes over both short (diurnal) and 


\begin{tabular}{|c|c|c|c|c|}
\hline \multicolumn{5}{|c|}{$\begin{array}{c}\text { TABLE } 2 \\
\text { Mean water temperature statistics for the Sani and } \\
\text { Bushman's River sites (January-May 2007) }\end{array}$} \\
\hline & TMean & $\begin{array}{l}\text { TMean } \\
\text { max }\end{array}$ & $\begin{array}{l}\text { TMean } \\
\text { min }\end{array}$ & $\begin{array}{c}\text { Water T lapse } \\
\text { rates }\end{array}$ \\
\hline & $\left({ }^{\circ} \mathrm{C}\right)$ & $\left({ }^{\circ} \mathrm{C}\right)$ & $\left({ }^{\circ} \mathrm{C}\right)$ & \\
\hline Sani River Site & & & & $1760-2860 \mathrm{~m}$ \\
\hline \multicolumn{5}{|l|}{$2860 \mathrm{~m}$} \\
\hline Jan & 15.5 & 24.9 & 7.6 & $-0.27^{\circ} \mathrm{C} / 100 \mathrm{~m}$ \\
\hline Feb & 15.3 & 25.3 & 6.8 & $-0.26^{\circ} \mathrm{C} / 100 \mathrm{~m}$ \\
\hline March & 12.8 & 23.7 & 5.1 & $-0.44^{\circ} \mathrm{C} / 100 \mathrm{~m}$ \\
\hline April & 9.5 & 18.7 & 0.9 & $-0.43^{\circ} \mathrm{C} / 100 \mathrm{~m}$ \\
\hline May & 6.1 & 13.9 & 0.6 & $-0.48^{\circ} \mathrm{C} / 100 \mathrm{~m}$ \\
\hline Bushmans River Site 1 & & & & $2280-2860 \mathrm{~m}$ \\
\hline \multicolumn{5}{|l|}{$2280 \mathrm{~m}$} \\
\hline Jan & 14.8 & 20.8 & 10.6 & $+0.12^{\circ} \mathrm{C} / 100 \mathrm{~m}$ \\
\hline Feb & 14.6 & 19.4 & 10.5 & $+0.12^{\circ} \mathrm{C} / 100 \mathrm{~m}$ \\
\hline March & 13.8 & 18.9 & 8.3 & $-0.17^{\circ} \mathrm{C} / 100 \mathrm{~m}$ \\
\hline April & 11.3 & 16.2 & 4.9 & $-0.31^{\circ} \mathrm{C} / 100 \mathrm{~m}$ \\
\hline May & 8.1 & 12 & 1.3 & $-0.34^{\circ} \mathrm{C} / 100 \mathrm{~m}$ \\
\hline Bushmans River Site 2 & & & & $2080-2280 \mathrm{~m}$ \\
\hline \multicolumn{5}{|l|}{$2080 \mathrm{~m}$} \\
\hline Jan & 15.7 & 20.3 & 10.4 & $-0.45^{\circ} \mathrm{C} / 100 \mathrm{~m}$ \\
\hline Feb & 15.5 & 19.6 & 11 & $-0.45^{\circ} \mathrm{C} / 100 \mathrm{~m}$ \\
\hline March & 14.9 & 19 & 11.2 & $-0.55^{\circ} \mathrm{C} / 100 \mathrm{~m}$ \\
\hline April & 11.4 & 15 & 5.9 & $-0.05^{\circ} \mathrm{C} / 100 \mathrm{~m}$ \\
\hline May & 8.8 & 11.1 & 4.5 & $-0.35^{\circ} \mathrm{C} / 100 \mathrm{~m}$ \\
\hline Bushmans River Site 3 & & & & $1760-2080 \mathrm{~m}$ \\
\hline \multicolumn{5}{|l|}{$1760 \mathrm{~m}$} \\
\hline Jan & 18.5 & 26.9 & 12.9 & $-0.88^{\circ} \mathrm{C} / 100 \mathrm{~m}$ \\
\hline Feb & 18.4 & 24.8 & 13 & $-0.91^{\circ} \mathrm{C} / 100 \mathrm{~m}$ \\
\hline March & 17.6 & 23.2 & 11.2 & $-0.84^{\circ} \mathrm{C} / 100 \mathrm{~m}$ \\
\hline April & 14.2 & 20.3 & 6.9 & $-0.88^{\circ} \mathrm{C} / 100 \mathrm{~m}$ \\
\hline May & 11.2 & 14.5 & 4.4 & $-0.81^{\circ} \mathrm{C} / 100 \mathrm{~m}$ \\
\hline
\end{tabular}

\begin{tabular}{|c|c|c|c|c|c|}
\hline \multicolumn{6}{|c|}{$\begin{array}{c}\text { TABLE } 3 \\
\text { Number of macroinvertebrate families present in } \\
\text { various biotypes at each site during summer, autumn } \\
\text { and winter of } 2006 / 07\end{array}$} \\
\hline \multirow[b]{2}{*}{ SUMMER } & \multicolumn{4}{|c|}{ Bushmans River sites } & \multirow{2}{*}{$\begin{array}{l}\text { Sani } \\
\text { River }\end{array}$} \\
\hline & 1 & 2 & 3 & $\begin{array}{l}\text { ALL } \\
\text { sites }\end{array}$ & \\
\hline Pools & 6.8 & 5.3 & 4.0 & 5.4 & 5.0 \\
\hline Chutes/riffles & 6.0 & 4.5 & 2.0 & 4.2 & \\
\hline Backwaters & NA & 4.5 & 5.0 & 4.8 & \\
\hline Glides & NA & NA & 3.0 & & \\
\hline Seasonal mean per biotype & 6.4 & 4.8 & 3.5 & 4.9 & \\
\hline TOTAL number for site & 16.0 & 13.0 & 9.0 & & \\
\hline \multicolumn{6}{|l|}{ AUTUMN } \\
\hline Pools & 4.3 & 3.7 & 4.3 & 4.1 & NA \\
\hline Chutes/riffles & 7.3 & 6.0 & 2.5 & 5.3 & \\
\hline Backwaters & $\mathrm{NA}$ & 4.0 & 6.0 & 5.0 & \\
\hline Glides & $\mathrm{NA}$ & NA & 8.0 & & \\
\hline Seasonal mean per biotype & 5.8 & 4.6 & 5.2 & 5.2 & \\
\hline TOTAL number for site & 14.0 & 9.0 & 10.0 & & \\
\hline \multicolumn{6}{|l|}{ WINTER } \\
\hline Pools & 4.0 & 3.7 & 3,7 & 3.8 & 4.0 \\
\hline Chutes/riffles & 4.0 & 3.0 & 5.0 & 4.0 & \\
\hline Backwaters & NA & 4,5 & 2.0 & 3.3 & \\
\hline Glides & $\mathrm{NA}$ & $\mathrm{NA}$ & 2.0 & & \\
\hline Seasonal mean per biotype & 4.0 & 3.4 & 3.2 & 3.5 & \\
\hline TOTAL number for site & 10.0 & 8.0 & 7.0 & & \\
\hline
\end{tabular}

$N A=$ not available

Site 1: $n=4$ pools, 3 chutes/riffles

Site 2: $n=3$ pools, 2 chutes/riffles, 2 backwaters

Site 3: $n=3$ pools, 2 chutes/riffles, 1 backwater, 1 glide

Sani site: $n=1$ pool

longer (years) time scales.

Mean monthly water temperatures began to notably decrease from February to March at higher stream altitudes (2 280 and $2860 \mathrm{~m}$ amsl), whilst cooling was delayed towards April for lower altitude sites (Table 2). This was also reflected in the water temperature lapse rates which were relatively high between $1760-2030 \mathrm{~m}$ amsl $\left(-0.84^{\circ} \mathrm{C} / 100 \mathrm{~m}\right)$, whilst lapse rates were reduced between $2080-2280 \mathrm{~m}$ amsl $\left(-0.55^{\circ} \mathrm{C} / 100\right.$ $\mathrm{m})$ and $2280-2860 \mathrm{~m}$ amsl $\left(-0.17^{\circ} \mathrm{C} / 100 \mathrm{~m}\right)$ during March. Patterns of cooling rates were however spatially complex with no notable change in water temperatures between 2080 and $2280 \mathrm{~m}$ amsl during April (lapse rate: $-0.05^{\circ} \mathrm{C} / 100 \mathrm{~m}$ ); yet between 2280 and $2860 \mathrm{~m}$ the cooling rate intensified to $-0.31^{\circ} \mathrm{C} / 100 \mathrm{~m}$ over the same period. The diurnal water temperature range decreased progressively towards winter (late May) for all altitudes but was most pronounced for the lower site (64\% reduction in diurnal temperature range) and least so for the Sani site (29\% reduction in diurnal temperature range). Mean water temperatures during May 2007 varied from $11.2^{\circ} \mathrm{C}$ to $6.2^{\circ} \mathrm{C}$ for the lower Bushmans and Sani River sites respectively, and absolute minimum temperatures approached $0^{\circ} \mathrm{C}$ at $2860 \mathrm{~m}$ amsl where surface ice was observed during logger retrieval on 26 May 2007. The overall altitudinal (1 $100 \mathrm{~m}$ ) trend of stream water cooling up the Drakensberg

escarpment was one of increased rates of cooling from mid summer towards winter (i.e., from $-0.27^{\circ} \mathrm{C} / 100 \mathrm{~m}$ (Jan) to $-0.48^{\circ} \mathrm{C} / 100 \mathrm{~m}$ (May))(Table 2).

\section{Macroinvertebrate community structure}

Macroinvertebrate species were recorded within various geomorphic biotypes so as to determine temporal trends within and between individual sites. During summer, the total number of macroinvertebrate families identified decreased substantially (by 69\%) with altitude, from 16 (lower site) to 5 (Sani site). This may have been a function of both decreasing water temperature and decreasing variability of hydrologic biotypes with altitude. The number of macroinvertebrate families identified decreased at all sites as water temperatures decreased from summer through to early winter (late May), but notably the highest percentage change was at the mid-tolower altitude Bushmans River sites (approx. 37-38\% reduction in families), and the lowest at the two higher altitude sites (20-23\% reduction in families) (Table 3$)$. It is possible that the substantial water temperature cooling to freezing conditions during winter and high diurnal temperature cycles during summer, when mean minimum temperatures dropped to approx. $7.2^{\circ} \mathrm{C}$ at the Sani site, restricted macroinvertebrate families to approx. 4-5 throughout the year.

The Ephemeropteran families Leptophlebiidae, Baetidae and Heptageniidae were generally the most abundant along 

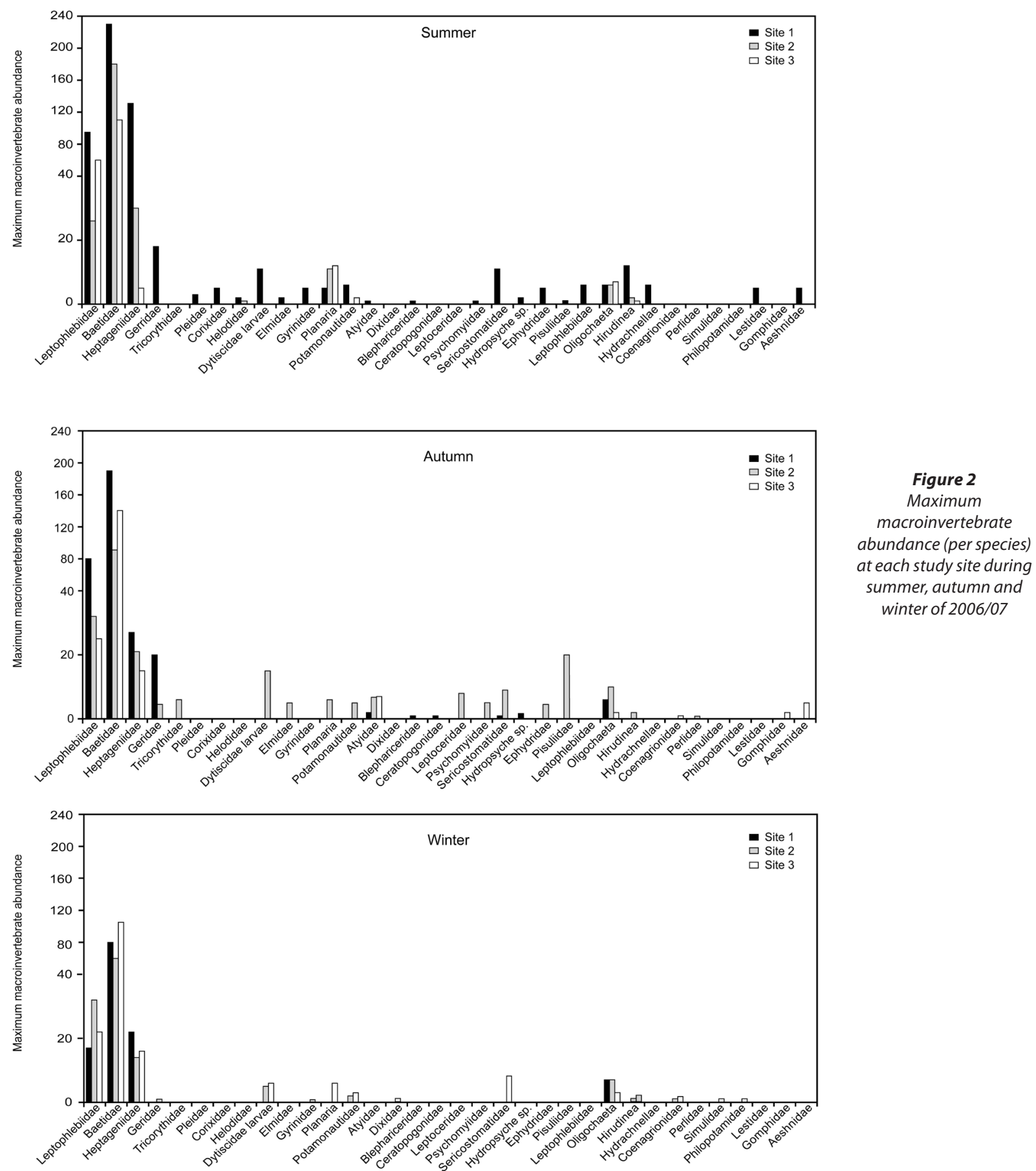

the Bushmans River (Fig. 2). The abundance of other families was generally small and the diversity of families varied altitudinally. The abundance of specific families generally decreased with altitude during most seasons. Maximum abundances of individuals for the families Baetidae (230) Heptageniidae (131) and Leptophlebiidae (95) were recorded at the lower site during summer, whilst at the upper site total numbers during summer were 110,5 and 45 , respectively. Despite this, and the lower diversity of macroinvertebrates at higher altitudes, total abundance decreased most substantially from summer to early winter at the lower site (by $74 \%$ ), and least at the upper site (by $11 \%$ ). This suggests that inter-seasonal macroinvertebrate population dynamics increased in stability with distance upstream along the upper
Bushmans River. The greatest seasonal (summer to early winter) decrease in abundance was recorded for Heptageniidae (by $69 \%$ ), followed by Baetidae (66\%) and Leptophlebiidae (57\%). Macroinvertebrate abundance decreased by $31 \%$ from mid-summer to early-autumn ( 3 months) across all sites, but decreased further by $38 \%$ from early autumn to early winter (2 months) when water temperatures decreased most substantially (Fig. 2).

The Bray-Curtis dissimilarity statistic demonstrates considerable spatial and temporal differences in macroinvertebrate populations (Fig. 3). The highest dissimilarity (54.2\%) occurred between the upper and lower Bushmans River sites in summer. Dissimilarity progressively decreased across the altitudinal gradient to $34.7 \%$ in autumn and $18.3 \%$ in winter. 


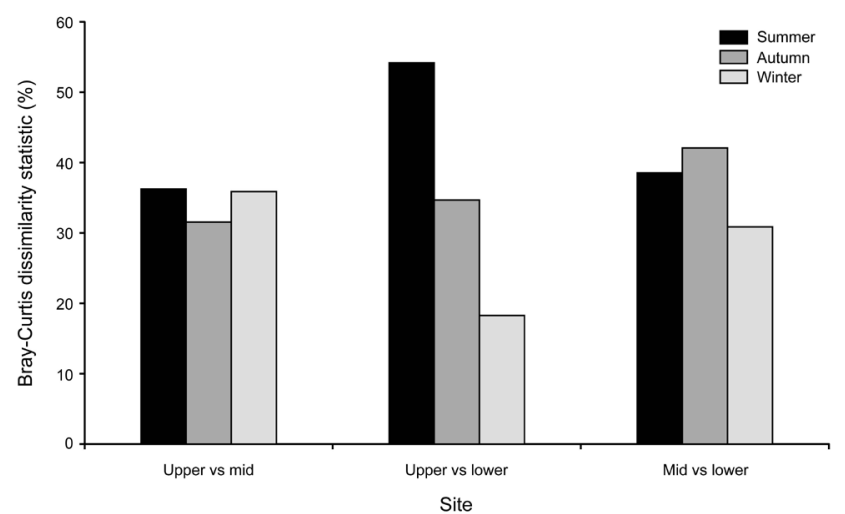

Figure 3

Bray-Curtis dissimilarity statistic run to compare the macroinvertebrate population biology between the upper, mid and lower Bushmans River sites during summer-autumnwinter of 2006/07

However, it seems that whilst there was a generally consistent dissimilarity across seasons for the upper vs. mid sites (maximum of $36.3 \%$ in summer to minimum of $31.6 \%$ in autumn), there was greater dissimilarity between the mid and lower sites, most particularly in autumn (42.1\%).

Macroinvertebrate assemblages were also assessed across various hydraulic biotypes including riffles/glides, pools and backwater/slackwater reaches. During summer, the number of macroinvertebrate families had a relatively high variance (2.6) across 7 biotype sampling localities at the lower site; variance across the mid and upper sites was lower (1.8 and 1.6 , respectively). The spatial variance for the number of macroinvertebrate families across sites increased considerably during autumn at all altitudes but was substantially higher at the lower site (8.2) than the two upper sites (3.2 and 3.9, respectively), which suggests strong spatial macroinvertebrate population readjustments across hydraulic biotypes, despite the average number of families per biotype $($ mean $=4.9)$ not having changed since mid-summer. In contrast, the average number of macroinvertebrate families per biotype decreased by approx. $23 \%$ to 3.8 by early winter, when the number of macroinvertebrate families had the lowest variance across the seven biotypes measured per site (mean $=1.7$ ), yet remained comparable to summer levels of variance at the lower site (2.6). Such patterns may reflect the maintenance of contrasting hydraulic biotypes at lower altitudes along the upper Bushmans River, whilst at higher altitudes such contrasts are more constrained.

Pools and backwaters had higher mean numbers of macroinvertebrate families during summer (5.4 and 4.8, respectively) than riffles (4.2), which was a likely function of a synergistic set of factors such as available food sources, water temperature and other hydro-physical controls. During autumn, when there seemed to be an apparent redistribution of macroinvertebrate populations across fluvial biotypes, there was a reverse trend in the number of families across such biotypes $($ riffles $=5.3$; backwaters $=5.0$; pools $=4.1$ ) (Table 3 ). However, the pattern had again changed by early winter when riffles continued to host the highest number of families (4.0), followed closely by pools (3.8), but backwaters had particularly low numbers of families represented (3.3). This again is likely a function of contrasting food availability and water temperatures across these biotypes.

\section{CONCLUSIONS}

In this study, decreasing water temperatures, both spatially (with increasing altitude) and seasonally (from summer to winter), and/or decreasing diversity of hydraulic biotypes associated with upstream-channel narrowing in Drakensberg rivers/streams, are associated with a general decrease in the absolute number of macroinvertebrate families, a lower dissimilarity coefficient along the Bushmans River altitudinal transect, and decreasing variance in the numbers of macroinvertebrate families across various hydraulic biotypes. These results are new to the Drakensberg region but in agreement with other temperature-driven macroinvertebrate community trends reported in other mountain environments or in association with climate warming (e.g. Miserendino, 2001; Milner et al., 2001; Burgmer et al., 2007). Contemporary altitudinal climate variability and substratum have a direct control on stream/river water temperature along altitudinal gradients, and this paper has demonstrated a variable water temperature lapse rate that may, at least in part, contribute to spatio-temporal changes in observed macroinvertebrate communities. At the micro-scale, hydraulic biotypes also contribute to species richness and abundance (Curry et al., 2012). Climate change/variability is likely to impact on these systems and have important implications for macroinvertebrate communities, particularly those occurring at the uppermost fluvial reaches; here warming resulting in the upward shift of thermal habitats may have ecological implications which cannot yet be accurately projected into the near future. Following this preliminary investigation, and to permit modelling of future trends under global change scenarios, it is proposed that long-term (multiple years) monitoring of stream temperatures and macroinvertebrates through an improved altitudinal spatial density of monitoring sites be considered for the Drakensberg/Lesotho mountain region.

\section{ACKNOWLEDGEMENTS}

The National Research Foundation is thanked for financial support (GUN: 2054113) provided to undertake this work. KZN Ezemvelo Wildlife is thanked for permission to work in the Drakensberg Park, and I appreciate the valuable field assistance offered by Bradley Johnson and Lezanne Raines, as also constructive comments from two anonymous referees.

\section{REFERENCES}

ANDREW NR, RODGERSON L and DUNLOP M (2003) Variation in invertebrate-bryophyte community structure at different spatial scales along altitudinal gradients. J. Biogeogr. 30 731-746.

AZRINA MZ, YAP CK, ISMAIL AR, ISMAIL A and TAN SG (2006) Anthropogenic impacts on the distribution and biodiversity of benthic macroinvertebrates and water quality of the Langat River, Peninsular Malaysia. Ecotoxicol. Environ. Saf. 64 337-347.

BARNARD KH (1927) A study of the freshwater isopodan and amphipodan Crustacea of South Africa. Trans. R. Soc. S. Afr. 14 139-215.

BATE G, SMAILES P and ADAMS J (2004) A water quality index for use with diatoms in the assessment of rivers. Water $S A$ 30 493-498.

BEISEL J-N, USSRGLIO-POLATERA P, THOMAS S and MORETEAU J-C (1998) Stream community structure in relation to spatial variation: the influence of mesohabitat characteristics. Hydrobiologia 389 73-88.

BONADA N, RIERADEVALL M and PRAT N (2006) Benthic macroinvertebrate assemblages and macrohabitat connectivity in 
Mediterranean-climate streams of northern California. J. N. Am. Benthol. Soc. 25 (1) 32-43.

BROWN AV and BRUSSOCK PP (1991) Comparison of benthic invertebrates between riffles and pools. Hydrobiologia 220 99-108

BROWN GW (1969) Predicting temperatures of small streams. Water Resour. Res. 5 68-75.

BURGMER T, HILLEBRAND H and PFENNINGER M (2007) Effects of climate-driven temperature changes on the diversity of freshwater macroinvertebrates. Oecologia 151 93-103.

CÉRÉGHINO R, GIRAUDEL JL and COMPIN A (2001) Spatial analysis of stream invertebrate distribution in the Adour-Garrone drainage basin (France) using Kohonen self-organization maps. Ecol. Model. 146 (1-3) 167-180.

CHESSMAN BC (2009) Climatic changes and 13-year trends in stream macroinvertebrate assemblages in New South Wales, Australia. Global Change Biol. 15 2791-2802.

CHUTTER FM (1972) An empirical biotic index of the quality of water in South African streams and rivers. Water Res. 6 19-30.

CLARKE KR, SOMERFIELD PJ and CHAPMAN MG (2006) On resemblance measures for ecological studies, including taxonomic dissimilarities and a zero-adjusted Bray-Curtis coefficient for denuded assemblages. J. Exp. Mar. Biol. Ecol. 330 55-80.

CLARK E, WEBB BW and LADLE M (1999) Microthermal gradients and ecological implications in Dorset rivers. Hydrol. Process. 13 423-438.

COMPIN A and CÉRÉGHINO R (2007) Spatial patterns of macroinvertebrate functional feeding groups in streams in relation to physical variables and land-cover in Southwestern France. Landscape Ecol. 22 1215-1225.

COX TJ and RUTHERFORD JC (2000) Thermal tolerances of two stream invertebrates exposed to diurnally varying temperature. New Zeal. J. Mar. Freshwater Res. 34 203-208.

CURRY CJ, CURRY RA and BAIRD DJ (2012) The contribution of riffles and riverine wetlands to benthic macroinvertebrate biodiversity. Biodivers. Conserv. 21 895-913.

DALLAS HF (2004) Spatial variability in macroinvertebrate assemblages: comparing regional and multivariate approaches for classifying reference sites in South Africa. Afr. J. Aquat. Sci. 29 (2) $161-171$.

DALLAS HF (2007) The effect of water temperature on aquatic organisms: A review of knowledge and methods for assessing biotic responses to temperature. WRC Report No. KV 213/09. Water Research Commission, Pretoria.

DALLAS HF (2008) Water temperature and riverine ecosystems: An overview of knowledge and approaches for assessing biotic responses, with special reference to South Africa. Water SA 34 (3) 393-404.

DALLAS HF, JANSSENS MP and DAY JA (1999) An aquatic macroinvertebrate and chemical database for riverine ecosystems. Water SA 25 (1) 1-8.

DAVY-BOWKER J, SWEETING W, WRIGHT N, CLARKE RT and ARNOTT S (2006) The distribution of benthic and hyporheic macroinvertebrates from the heads and tails of riffles. Hydrobiologia 563 109-123.

DEWSON ZS, JAMES ABW and DEATH RG (2007) Invertebrate community responses to experimentally reduced discharge in small streams of different water quality. J. N. Am. Benthol. Soc. 26 (4) 754-766

DICKENS C and GRAHAM M (2002) South African Scoring System (SASS) Version 5 rapid bioassessment method for rivers. Afr. J. Aquat. Sci. 27 (1) 1-10.

DURANCE I and ORMEROD SJ (2007) Climate change effects on upland stream macroinvertebrates over a 25 -year period. Global Change Biol. 13 942-957.

FINN DS and POFF L (2005) Variability and convergence in benthic communities along the longitudinal gradients of four physically similar Rocky Mountain streams. Freshwater Biol. 50 243-261.

HARI RE, LIVINGSTONE DM, SIBER R, BURKHARDT-HOLM P and GÜTTINGER H (2006) Consequences of climatic change for water temperature and brown trout populations in Alpine rivers and streams. Global Change Biol. 12 10-26.
HURYN AD and WALLACE B (1987) Local geomorphology as a determinant of macrofaunal production in a mountain stream. Ecology 68 (6) 1932-1942.

HUTCHINSON GE (1929) A revision of the Notonectidae and Corixidae of South Africa. Ann. S. Afr. Mus. 25 359-474.

JACOBSEN D (2004) Contrasting patterns in local and zonal family richness of stream invertebrates along an Andean altitudinal gradient. Freshwater Biol. 49 1293-1305.

JACOBSEN D, SCHULTZ R and ENCALADA A (1997) Structure and diversity of stream invertebrate assemblages: the influence of temperature with altitude and latitude. Freshwater Biol. 38 247-261.

JOHNSON SL (2004) Factors influencing stream temperatures in small streams: substrate effects and a shading experiment. Can. J. Fish. Aquat. Sci. 61 913-923.

JOWETT IG and RICHARDSON J (1990) Microhabitat preferences of benthic invertebrates in a New Zealand river and the development of in-stream flow-habitat models for Deleatidium spp. New Zeal. J. Mar. Freshwater Res. 24 19-30.

KING J and LOUW D (1998) Instream flow assessments for regulated rivers in South Africa using the Building Block Methodology. Aquat. Ecosyst. Health Manage. 1 (2) 109-124.

LAMBERTI GA, GREGORY SV, ASHKENAS LR, WILDMAN RC and STEINMAN AD (1989) Influence of channel geomorphology on retention of dissolved and particulate matter in a cascade mountain stream. USDA Forest Service General Technical Report PSW-110 33-39. United States Department of Agriculture, Washington D.C.

LARSEN S and ORMEROD SJ (2010) Low-level effects of inert sediments on temperate stream invertebrates. Freshwater Biol. 55 476-486.

LAWRENCE JE, LUNDE KB, MAZOR RD, BÊCHE LA, McELRAVY EP and RESH VH (2010) Long-term macroinvertebrate responses to climate change: implications for biological assessment in Mediterranean-climate streams. J. N. Am. Benthol. Soc. 29 1424-1440.

MALHERBE W, WEPENER V and VAN VUREN JHJ (2010) Anthropogenic spatial and temporal changes in the aquatic macro-invertebrate assemblages of the lower Mvoti River, KwaZulu-Natal, South Africa. Afr. J. Aquat. Sci. 35 13-20.

MILNER AM, BRITTAIN JE, CASTELLA E AND PETTS GE (2001) Trends of macroinvertebrate community structure in glacierfed rivers in relation to environmental conditions: a synthesis. Freshwater Biol. 46 1833-1847.

MISERENDINO ML (2001) Macroinvertebrate assemblages in Andean Patagonian rivers and streams: environmental relationships. Hydrobiologia 444 147-158.

MOOR AA and PALMER MA (2005) Invertebrate biodiversity in agricultural and urban headwater streams: implications for conservation and management. Ecol. Appl. 15 1169-1177.

MOOR RD, SUTHERLAND P, GOMI T and DHAKAL A (2005) Thermal regime of a head water stream within a clear-cut coastal British Columbia, Canada. Hydrol. Process. 19 2591-2608.

OLLIS DJ, DALLAS HF, ESLER KJ and BOUCHER C (2006) Bioassessment of the ecological integrity of river ecosystems using aquatic macroinvertebrates: an overview with a focus on South Africa. Afr. J. Aquat. Sci. 31 (2) 205-227.

POWER ME, PARKER G, DIETRICH WE and SUN A (1995) How does floodplain width affect floodplain river ecology? A preliminary exploration using simulations. Geomorphology 13 301-317.

ROUX DJ, KLEYNHANS CJ, THIRION C, HILL L, ENGELBRECHT JS, DEACON AR and KEMPER NP (1999) Adaptive assessment and management of riverine ecosystems: The Crocodile/Elands River case study. Water SA 25 (4) 501-512.

ROWNTREE K and WADESON R (1999) A hierarchical geomorphological model for the classification of selected South African rivers. WRC Report No 497/1/99. Water Research Commission, Pretoria.

SMITH H, WOOD PJ and GUNN J (2003) The influence of habitat structure and flow permanence on invertebrate communities in karst spring systems. Hydrobiologia 510 (1-3) 53-66.

STENERT C, BACCA RC, MOSTARDEIRO CC and MALTCHIK L (2008) Environmental predictors of macroinvertebrate 
communities in coastal wetlands of southern Brazil. Mar. Freshwater Res. 59 540-548.

WANG Z, MELCHING CS, DUAN X and YU G (2009) Ecological and hydraulic studies of step-pool systems. J. Hydraul. Eng. 135 (9) 705-717.

WEBB BW, HANNAH DM, MOORE RD, BROWN LE and NOBILIS $\mathrm{F}$ (2008) Recent advances in stream and river temperature research. Hydrol. Process. 22 902-918.
WONG DCL, MALTBY L, WHITTLE D, WARREN P and DORN PB (2004) Spatial and temporal variability in the structure of invertebrate assemblages in control stream mesocosms. Water Res. 38 (1) $128-138$.

YARNELL SM, MOUNT JF and LARSEN EW (2006) The influence of relative sediment supply on riverine habitat heterogeneity. Geomorphology 80 310-324. 